\title{
HETEROCYCLES 50. SYNTHESIS AND CHARACTERIZATION OF NEW 2-PHENYLAMINOTHIAZOLE DERIVED MANNICH BASES BY BIOCATALYTIC MULTICOMPONENT REACTIONS
}

\author{
DENISA LEONTE ${ }^{a}$, ROBERT TŐTŐS $^{\mathrm{b}}$, VALENTIN ZAHARIA $^{\mathrm{a},{ }^{*}}$
}

\begin{abstract}
In this work we describe the synthesis and characterization of new Mannich bases derived from 2-phenylaminothiazole, by applying the trimolecular condensation of thiazole aldehydes with aniline and acetone, catalyzed by lipase B from Candida antarctica. The target compounds were obtained with $68-76 \%$ yields, in mild and eco-friendly reaction conditions. The new heterocyclic Mannich bases were characterized by melting points, ${ }^{1} \mathrm{H}$ NMR, ${ }^{13} \mathrm{C}$ NMR and MS spectrometry.
\end{abstract}

Keywords: thiazole, Mannich base, lipase, multicomponent reactions

\section{INTRODUCTION}

Multicomponent reactions have a great synthetic value because of their practical simplicity, rapidity and high atom economy. In particular, the three component Mannich reaction has become a versatile tool in drug discovery and modern synthetic chemistry, as a key step for new C-C and C-N bond forming. The classical procedure is based on the use of formaldehyde as carbonyl component, a secondary amine as nucleophile and an enolisable carbonyl compound as $\mathrm{CH}$-acidic substrate. Other variants of the Mannich reaction have been reported, most part being focused on the variation of the component with mobile hydrogen or the nucleophilic component [1],[2].

\footnotetext{
a "Iuliu Hațieganu" University of Medicine and Pharmacy, Department of Organic Chemistry, 41 Victor Babeş str., RO-400012 Cluj-Napoca, Romania

b Babeş-Bolyai University, Faculty of Chemistry and Chemical Engineering, Biocatalysis and Biotransformations Research Group, 11 Arany Janos str., RO-400028, Cluj-Napoca, Romania

*Corresponding author: vzaharia@umfcluj.ro
} 
In the pharmaceutical field, Mannich reaction allows the assembly of different pharmacophore units in the same molecule, with the possibility of structural modulation by varying the carbonyl moiety, the nucleophilic component as well as the component with mobile hydrogen [2].

Beta-amino carbonyl compounds, the products of the Mannich reaction, are recognized to present different biological activities such as antibacterial, antifungal, antiviral, anti-inflammatory and anticancer properties [3]. New $\beta$ amino ketones obtained by a three-component coupling Mannich reaction were reported to present antifungal activity against Candida albicans, as well as good antibacterial activity against Bacillus subtilis, Escherichia coli, Staphylococcus aureus and Pseudomonas aeruginosa strains [4]. Pharmacophore prediction studies revealed similar interactions and orientation of the active molecules with a potential protein-binding site and confirmed the important role of the hydrophilic moieties (NH group), the hydrophobic ones (the aryl rings) and their relative distance. It was found that the minimal structural requirements for the antimicrobial activity of $\beta$-amino ketones consist of an aromatic ring (hydrophobic region) attached to the $\mathrm{NH}$ group ( $\mathrm{H}$-bonding donor area) and a carbonyl fragment, as $\mathrm{H}$-bonding acceptor region [4].

The 2-aminothiazole system is an important pharmacophore present in the structure of many therapeutic agents, such as the anti-inflammatory drug meloxicam, the dopamine agonist pramipexole and the cephalosporin antibiotic cefdinir. In particular, the 2-phenylaminothiazole scaffold can be found in the structure of new bioactive compounds with antitubercular [5] and antileishmanial properties [6].

Enzyme catalyzed reactions are of great value in organic synthesis because they offer multiple possibilities to perform difficult transformations under mild reaction conditions and with high selectivity. Lipases offer efficient routes towards variously functionalized compounds, such as alcohols [7],[8], esters [9],[10], amines [11], amides [12], amino acids [13] and $\beta$-hydroxyacids. [14] Moreover, lipases proved to be effective biocatalysts for the formation of novel C-C and C-N bonds in Mannich-type multicomponent reactions [15],[16]. In previous researches, we have applied the Mannich type enzymatic reaction starting from 2-arylthiazole aldehydes as carbonyl substrates, with Candida antarctica lipase $B$ as biocatalyst [17].

In the continuation of these researches and being aware of the biological potential of the 2-phenylaminothiazole scaffold, we decided to extend the lipase catalyzed multicomponent Mannich type reaction in the series of aldehydes derived from 2-phenylaminothiazole, in order to access new Mannich bases for medicinal applications. 
HETEROCYCLES 50. SYNTHESIS AND CHARACTERIZATION OF NEW 2-PHENYLAMINOTHIAZOLE DERIVED MANNICH BASES BY BIOCATALYTIC MULTICOMPONENT REACTIONS

\section{RESULTS AND DISCUSSION}

The aim of this study was to obtain new heterocyclic compounds with biological potential, bearing the 2-phenylaminothiazole scaffold, by mild and ecofriendly reaction conditions. In this sense, we oriented us researches to the investigation of the enzyme catalyzed trimolecular Mannich type condensation of different 2-phenylaminothiazole derived aldehydes with aniline and acetone.

The first step was the synthesis of 2-arylaminothiazole aldehydes 1a-c, necessary as substrates in the Mannich type condensation. Their synthesis was performed as previously described by us, starting from the corresponding aryl isothiocyanates, by addition of ammonia, followed by Hantzsch condensation of arylthioureas with 1,3-dichloroacetone, $\mathrm{N}$-acetylation and Sommelet reaction (Scheme 1) [18].

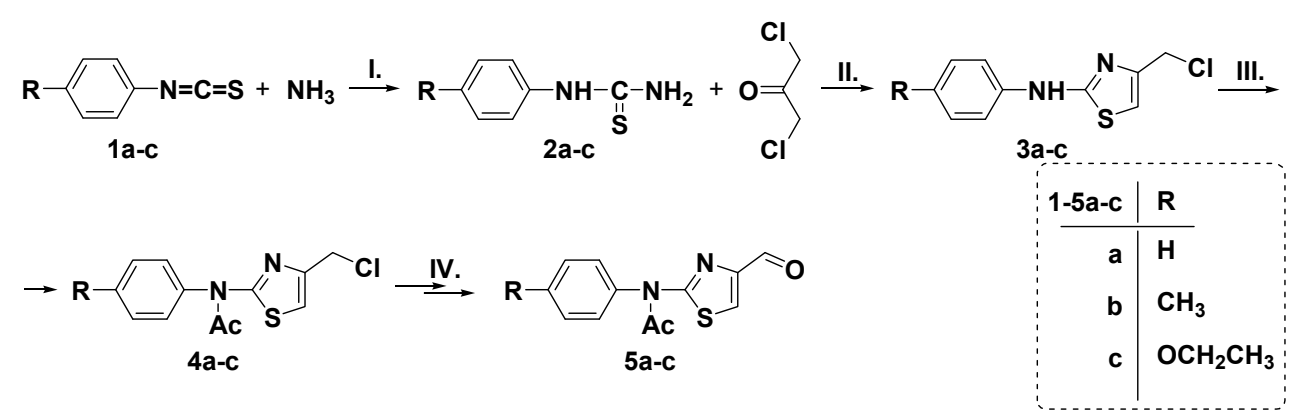

Scheme 1. Synthesis of thiazole aldehydes 5a-c. Reaction conditions: I. $\mathrm{NH}_{4} \mathrm{OH}$ $20 \%$, r.t. $24 \mathrm{~h}$, II. ethanol, reflux $1 \mathrm{~h}$, III. Acetic anhydride, reflux $10 \mathrm{~min}$, IV. 1. urotropin, $\mathrm{CHCl}_{3}$, reflux 1h, 2. urotropin, $\mathrm{CH}_{3} \mathrm{COOH} 50 \%$, reflux 1h. [18]

First enzymatic experiments were performed at analytical scale, in order to find the optimal reaction conditions. Various lipases (lipase from Burkholderia cepacia, lipase from Candida rugosa, lipase from Pseudomonas fluorescens, lipase B from Candida antarctica) have been evaluated as biocatalysts for the direct Mannich condensation between the obtained thiazole aldehydes, aniline and acetone, in aqueous media. Control experiments were also performed, in the absence of the enzyme and in the presence of bovine serum albumin. It is known that the presence of water in the reaction media strongly influence the activity of lipases in the Mannich type condensation, the optimal water concentration being between $40 \%$ and $50 \%$. [15],[16] Consequently, in our experiments we choose an acetone/water 1:1 v/v mixture as the reaction media, taking into account also the low solubility in water of the used thiazole aldehydes. The enzymatic reactions were conducted at room temperature, under continuous shaking at $1200 \mathrm{rpm}$. 
TLC analysis of preliminary experiments at analytical scale revealed that lipases from Candida rugosa, Pseudomonas fluorescens and lipase B from Candida antarctica presented good catalytic activity in the transformation of the substrates. In the absence of the enzyme or in the presence of bovine serum albumin, the formation of Mannich bases was not detected. Lipase $B$ from Candida antarctica (CaL-B, Novozym 435) was chosen for further studies, because in this case total conversion was achieved.

In further experiments, we opted for the use of aniline sulfate instead of aniline, because of its better stability, easier manipulation and storage. Good results were also obtained when aniline sulfate was used in the enzymatic reactions, in the presence of sodium acetate.

The preparative scale enzymatic synthesis of Mannich bases 6a-c was performed in the presence of CaL-B (Novozym 435) as biocatalyst (Scheme 2). Aniline was added in excess (1.1 eq.) in order to ensure the total consumption of the heterocyclic aldehyde. The Mannich bases 6a-c were obtained with $68-76 \%$ yields, starting from the corresponding $\mathrm{N}$-acetylated 2-arylaminothiazole aldehydes $(0.08 \mathrm{~mol} / \mathrm{L})$, aniline sulphate $(0.088 \mathrm{~mol} / \mathrm{L})$, sodium acetate $(0.088 \mathrm{~mol} / \mathrm{L})$, in the presence of $\mathrm{CaL}-\mathrm{B}$, in acetone/water $1 / 1 \mathrm{v} / \mathrm{v}$ mixture.

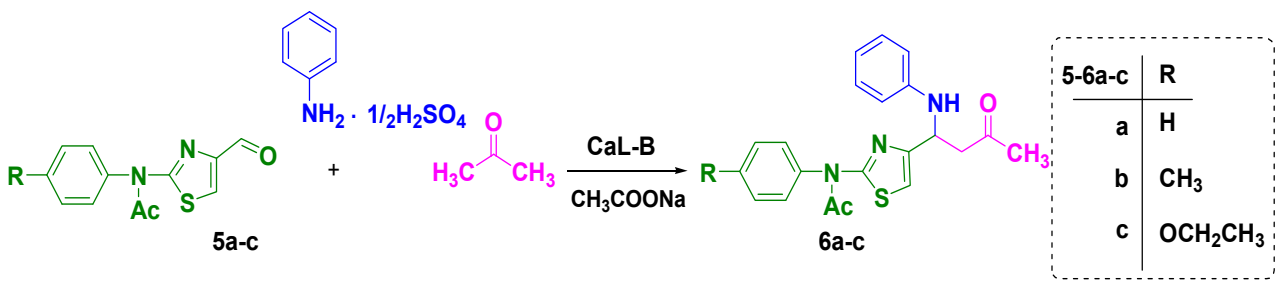

Scheme 2. Synthesis of 2-phenylaminothiazole derived Mannich bases 6a-c. Reaction conditions: Novozym $435(10 \mathrm{mg} / \mathrm{mL}), \mathrm{CH}_{3} \mathrm{COONa}(0.088 \mathrm{~mol} / \mathrm{L})$, acetone/water $1: 1 \mathrm{v} / \mathrm{v}$, r.t., $24 \mathrm{~h}$

The newly synthesised Mannich bases were purified, physically and chemically characterized by melting point, ${ }^{1} \mathrm{H}$ NMR, ${ }^{13} \mathrm{C} N M R$ and $\mathrm{MS}$ spectroscopy.

In the ${ }^{1} \mathrm{H}$ NMR spectra of Mannich bases $6 \mathbf{a}-\mathbf{c}$, the $\mathrm{CH}$ proton located in the $4^{\text {th }}$ position of the butanone chain appears as a triplet $(t)$ at 4.87-4.88 ppm and the $\mathrm{CH}_{2}$ protons located in the $3^{\text {th }}$ position of the butanone chain are appearing as a doublet of doublets of doublets (ddd), at chemical shifts of $2.76-2.79 \mathrm{ppm}$. The proton located in the $5^{\text {th }}$ position of the thiazole ring appears as a singlet (s) at $6.80-6.81 \mathrm{ppm}$. All signals corresponding to the protons located on the benzene rings are present in the aromatic region. 
HETEROCYCLES 50. SYNTHESIS AND CHARACTERIZATION OF NEW 2-PHENYLAMINOTHIAZOLE DERIVED MANNICH BASES BY BIOCATALYTIC MULTICOMPONENT REACTIONS

In the ${ }^{13} \mathrm{C}$ NMR spectra of compounds $6 \mathrm{a}-\mathrm{c}$, a characteristic signal between 207.70 and $207.76 \mathrm{ppm}$ indicates the presence of the carbonyl group of the butanone chain. The presence of the amide group is confirmed by a characteristic signal at $169.89-170.40$ ppm corresponding to the CO$\mathrm{NH}$ carbon. All aromatic and aliphatic signals are also present, thus confirming the chemical structures of the products.

The LC-MS spectra of the obtained Mannich bases confirm their structures by the presence of the $[\mathrm{M}+\mathrm{H}]^{+}$peak.

\section{CONCLUSIONS}

New 2-phenylaminothiazole derived Mannich bases were obtained by a three component biocatalytic reaction, starting from $\mathrm{N}$-acetylated 2arylaminothiazole aldehydes, aniline and acetone, in acetone/water mixture as reaction media, at room temperature.

The results of the presented study reveal that $\mathrm{N}$-acetylated 2arylaminothiazole aldehydes are novel substrates in the Cal-B catalyzed Mannich type condensation. The enzymatic reactions occurred without affecting the amide group present in the structure of the aldehydes used as substrates.

The applied biocatalytic method allowed us to obtain in good yields new pharmacologically useful Mannich bases containing the 2-phenylaminothiazole system, in mild and eco-friendly reaction conditions.

Spectral analyses MS, ${ }^{1} \mathrm{H}$ NMR and ${ }^{13} \mathrm{C}$ NMR confirm the structures of the newly obtained compounds.

\section{EXPERIMENTAL SECTION}

The ${ }^{1} \mathrm{H}$ NMR and ${ }^{13} \mathrm{C}$ NMR spectra were recorded on a Brucker Avance DPX-300 spectrometer operating at 600 and $150 \mathrm{MHz}$, respectively. Chemical shifts on the $\delta$ scale are expressed in ppm values from TMS as internal standard. MS spectra were recorded on Agilent 6410 Triple Quadrupole LC/MS mass spectrometry system.

Thin layer chromatography (TLC) was performed with Merck Kieselgel 60F254 sheets. Spots were visualized in UV light at $254 \mathrm{~nm}$. The purification of compounds was performed by column chromatography on Merck Kieselgel $60 \AA$ (63-200 $\mu \mathrm{m})$.

Melting points were determined on open glass capillaries using an Electrothermal IA 9000 digital apparatus.

The reagents and solvents necessary for the synthesis and purification of the target compounds and intermediates were purchased from Sigma Aldrich and Alfa Aesar. Aniline was purified by distillation under reduced pressure 
before use in the enzymatic reactions. Lipase B from Candida antarctica (CaL-B, Novozym 435) was purchased from Novozymes. Lipases from Pseudomonas fluorescens and Burkholderia cepacia were from Amano, England. Lipase from Candida rugosa (CrL) was purchased from Fluka.

\section{Lipase screening for the biocatalytic Mannich reaction. Analytical scale experiments}

To a solution of $\mathrm{N}$-acetyl-2-phenyaminothiazol-4-carbaldehyde $5 \mathrm{a}$ $(0.05 \mathrm{mmol}, 12.3 \mathrm{mg})$ dissolved in acetone $(0.4 \mathrm{~mL})$, aniline $(5 \mu \mathrm{L}, 0.055 \mathrm{mmol})$, deionized water $(0.4 \mathrm{~mL}$ ) and different lipases (10 mg of lipase from Burkholderia cepacia, lipase from Candida rugosa, lipase from Pseudomonas fluorescens, lipase $\mathrm{B}$ from Candida antarctica) were added in this order. The reaction mixtures were shaken at $1200 \mathrm{rpm}$ for $24 \mathrm{~h}$ and then analyzed by TLC using a mixture of petroleum ether: ethyl acetate $4: 1 \mathrm{v} / \mathrm{V}$ as mobile phase.

\section{Enzymatic Synthesis of Thiazole Mannich Bases 6a-c}

To a solution of heterocyclic aldehyde $5 \mathrm{a}-\mathbf{c}(1.6 \mathrm{mmol})$ dissolved in acetone $(10 \mathrm{~mL})$, aniline sulphate $(1.76 \mathrm{mmol}, 250 \mathrm{mg})$, deionized water $(10 \mathrm{~mL})$, sodium acetate $(1.76 \mathrm{mmol}, 144 \mathrm{mg})$ and CaL-B $(200 \mathrm{mg})$ were added in this order. The reaction mixtures were shaken at $1200 \mathrm{rpm}$ until complete consumption of aldehydes $5 \mathrm{a}-\mathrm{c}$ ( $36 \mathrm{~h}$, checked by TLC using a mixture of petroleum ether: ethyl acetate $4: 1 \mathrm{v} / \mathrm{v}$ as eluent). The formed Mannich bases precipitated in the reaction media and these were isolated by filtration. The enzyme was washed three times with acetone for the quantitative recovery of the reaction product. The crude product was purified by column chromatography, using as mobile phase a mixture of petroleum ether: ethyl acetate 4:1 $\mathrm{v} / \mathrm{v}$.

4-(Phenylamino)-4-(2-(N-phenylacetamido)thiazol-4-yl)butan-2-one

(6a) yellow solid, m.p. $143-144^{\circ} \mathrm{C}$, yield: $70 \% .{ }^{1} \mathrm{H}$ NMR $\left(600 \mathrm{MHz}, \mathrm{CDCl}_{3}\right)$ ס $7.60-7.47(\mathrm{~m}, 3 \mathrm{H}, \mathrm{Ar}-\mathrm{H}), 7.34-7.22(\mathrm{~m}, 2 \mathrm{H}, \mathrm{Ar}-\mathrm{H}), 7.15-7.07(\mathrm{~m}, 2 \mathrm{H}$, Ar-H), $6.81(\mathrm{~s}, 1 \mathrm{H}, \mathrm{CH}-5$ thiazole), $6.69(\mathrm{t}, \mathrm{J}=7.3 \mathrm{~Hz}, 1 \mathrm{H}, \mathrm{Ar}-\mathrm{H}), 6.57(\mathrm{~d}, \mathrm{~J}=$ $8.5 \mathrm{~Hz}, 2 \mathrm{H}, \mathrm{Ar}-\mathrm{H}$ ), 4.87 (t, J = 6.1 Hz, $1 \mathrm{H}, \mathrm{CH}-\mathrm{CH}_{2}-\mathrm{C}=\mathrm{O}$ ), 2.76 (ddd, J = 22.6, $\left.15.9,6.2 \mathrm{~Hz}, 2 \mathrm{H}, \mathrm{CH}-\mathrm{CH}_{2}-\mathrm{C}=\mathrm{O}\right), 2.03\left(\mathrm{~s}, 3 \mathrm{H},>\mathrm{N}-\mathrm{CO}-\mathrm{CH}_{3}\right), 1.85$ (s, 3H, $\left.-\mathrm{CO}-\mathrm{CH}_{3}\right)$. ${ }^{13} \mathrm{C}$ NMR $\left(151 \mathrm{MHz}, \mathrm{CDCl}_{3}\right) \delta 207.69,169.89,160.20,151.35,146.81$, 140.51, 130.00, 129.38, 129.18, 128.98, 118.19, 113.98, 110.24, 51.09, 47.85, 30.70, 23.93. LC-MS: $\mathrm{m} / \mathrm{z}$ found: 380.10 (M calculated for $\left[\mathrm{C}_{21} \mathrm{H}_{21} \mathrm{~N}_{3} \mathrm{O}_{2} \mathrm{~S}+\mathrm{H}^{+}\right.$]: 380.14);

4-(Phenylamino)-4-(2-(N-p-tolylacetamido)thiazol-4-yl)butan-2-one (6b) white solid, m.p. $149-150^{\circ} \mathrm{C}$, yield: $68 \%$. ${ }^{1} \mathrm{H}$ NMR $\left(600 \mathrm{MHz}, \mathrm{CDCl}_{3}\right)$ $\delta 7.33(\mathrm{~d}, \mathrm{~J}=8.0 \mathrm{~Hz}, 2 \mathrm{H}, \mathrm{Ar}-\mathrm{H}), 7.17-7.11(\mathrm{~m}, 4 \mathrm{H}, \mathrm{Ar}-\mathrm{H}), 6.80(\mathrm{~s}, 1 \mathrm{H}, \mathrm{CH}-$ 5 thiazole), $6.69(\mathrm{t}, \mathrm{J}=7.3 \mathrm{~Hz}, 1 \mathrm{H}, \mathrm{Ar}-\mathrm{H}), 6.58(\mathrm{~d}, \mathrm{~J}=7.9 \mathrm{~Hz}, 2 \mathrm{H}, \mathrm{Ar}-\mathrm{H}), 4.88$ (t, J = 6.1 Hz, $1 \mathrm{H}, \mathrm{CH}-\mathrm{CH}_{2}-\mathrm{C}=\mathrm{O}$ ), 2.78 (ddd, J = 22.5, 15.9, $6.2 \mathrm{~Hz}, 2 \mathrm{H}, \mathrm{CH}-$ $\mathrm{CH}_{2}-\mathrm{C}=\mathrm{O}$ ), $2.47\left(\mathrm{~s}, 3 \mathrm{H}, \mathrm{Ar}-\mathrm{CH}_{3}\right), 2.03\left(\mathrm{~s}, 3 \mathrm{H},>\mathrm{N}-\mathrm{CO}-\mathrm{CH}_{3}\right), 1.87(\mathrm{~s}, 3 \mathrm{H},-\mathrm{CO}-$ $\left.\mathrm{CH}_{3}\right) .{ }^{13} \mathrm{C} \mathrm{NMR}\left(151 \mathrm{MHz}, \mathrm{CDCl}_{3}\right) \delta 207.70,170.12,160.37,151.31,146.85$, 
HETEROCYCLES 50. SYNTHESIS AND CHARACTERIZATION OF NEW 2-PHENYLAMINOTHIAZOLE DERIVED MANNICH BASES BY BIOCATALYTIC MULTICOMPONENT REACTIONS

$139.17,137.90,130.59,129.36,128.63,118.17,113.98,110.20,51.14$, 47.91, 30.66, 23.90, 21.38. LC-MS: $\mathrm{m} / \mathrm{z}$ found: 394.10 (M calculated for $\left.\left[\mathrm{C}_{22} \mathrm{H}_{23} \mathrm{~N}_{3} \mathrm{O}_{2} \mathrm{~S}+\mathrm{H}^{+}\right]: 394.15\right)$;

4-(Phenylamino)-4-(2-(N-p-ethoxyphenylacetamido)thiazol-4-yl)butan-

2-one (6c) white solid, m.p. $152-153^{\circ} \mathrm{C}$, yield: $76 \%$. ${ }^{1} \mathrm{H}$ NMR $(600 \mathrm{MHz}$, $\left.\mathrm{CDCl}_{3}\right) \delta 7.16(\mathrm{~d}, \mathrm{~J}=8.8 \mathrm{~Hz}, 1 \mathrm{H}, \mathrm{Ar}-\mathrm{H}), 7.12(\mathrm{t}, \mathrm{J}=7.9 \mathrm{~Hz}, 2 \mathrm{H}, \mathrm{Ar}-\mathrm{H}), 7.02$ $(\mathrm{d}, \mathrm{J}=8.8 \mathrm{~Hz}, 2 \mathrm{H}, \mathrm{Ar}-\mathrm{H}), 6.80(\mathrm{~s}, 1 \mathrm{H}, \mathrm{CH}-5$ thiazole), $6.69(\mathrm{t}, \mathrm{J}=7.3 \mathrm{~Hz}, 1 \mathrm{H}$, Ar-H), 6.58 (d, J = 7.9 Hz, 2H, Ar-H), $4.88\left(\mathrm{t}, \mathrm{J}=6.1 \mathrm{~Hz}, 1 \mathrm{H}, \mathrm{CH}-\mathrm{CH}_{2}-\mathrm{C}=\mathrm{O}\right.$ ), $4.11\left(\mathrm{q}, \mathrm{J}=7.0 \mathrm{~Hz}, 2 \mathrm{H}, \mathrm{OCH}_{2} \mathrm{CH}_{3}\right.$ ), 2.79 (ddd, $\mathrm{J}=22.5,15.9,6.2 \mathrm{~Hz}, 2 \mathrm{H}$, $\mathrm{CH}-\mathrm{CH}_{2}-\mathrm{C}=\mathrm{O}$ ), $2.04\left(\mathrm{~s}, 3 \mathrm{H},>\mathrm{N}-\mathrm{CO}-\mathrm{CH}_{3}\right), 1.90\left(\mathrm{~s}, 3 \mathrm{H},-\mathrm{CO}-\mathrm{CH}_{3}\right), 1.48(\mathrm{t}, \mathrm{J}=7.0$ $\left.\mathrm{Hz}, 3 \mathrm{H}, \mathrm{OCH}_{2} \mathrm{CH}_{3}\right) .{ }^{13} \mathrm{C} \mathrm{NMR}\left(151 \mathrm{MHz}, \mathrm{CDCl}_{3}\right) \delta 207.76,170.40,160.54$, 159.33, 151.27, 146.86, 132.99, 129.91, 129.37, 118.17, 115.54, 114.00, 110.24, 63.97, 51.15, 47.96, 30.74, 23.90, 14.93. LC-MS: $\mathrm{m} / \mathrm{z}$ found: 424.10 (M calculated for $\left.\left[\mathrm{C}_{23} \mathrm{H}_{25} \mathrm{~N}_{3} \mathrm{O}_{3} \mathrm{~S}+\mathrm{H}^{+}\right]: 424.16\right)$.

\section{REFERENCES}

1. A. Toma, D. Hapău, M. Naghi, L. Vlase, C. Mogoşan, V. Zaharia, Studia UBB Chemia, 2013, 2, 93-104.

2. V.M. Patel, N.B. Patel, M.J. Chan-Bacab, G. Rivera, Comput. Biol. Chem., 2018, 76, 264-274.

3. S. Bala, N. Sharma, A. Kajal, S. Kamboj, V. Saini, Int. J. Med. Chem. 2014, ID 191072.

4. A.M. El-Bayouki, W.M. Basyouni, A.S. El-Sayed, W.M. Tohamy, A.A. ElHenawyb, Croat. Chem. Acta, 2012, 85 (3), 255-268.

5. M. Pieroni, B. Wan, S. Cho, S.G. Franzblau, G. Costantino, Eur. J. Med. Chem., 2014, 72, 26-34.

6. D. Bhuniya, R. Mukhhavilli, R. Dhivhare, D. Launay, R. Dere, A. Deshpandey, A. Verma, P. Vishwakarma, M. Moger, A. Pradhan, H. Pati, V. S. Gopinath, S. Gupta, S. Puri, D. Martin, Eur. J. Med. Chem., 2015, 102, 582-593.

7. M.E. Moisă, L. Poppe, C.A. Gal, L.C. Bencze, F.D. Irimie, C. Paizs, M.I. Toşa, Reaction Chemistry \& Engineering, 2018, 3(5), 790-798.

8. D. Hapău, J. Brem, V. Zaharia, Tetrahedron: Asymmetry, 2011, 22(24), 21652171.

9. D. Hapău, J. Brem, M. Moisă, M.I. Toşa, F.D. Irimie, V. Zaharia, J. Mol. Cat. B: Enzym., 2013, 94, 88-94.

10. M.A. Lăcătuş, L.C. Bencze, M.I. Toşa, C. Paizs, F.D. Irimie, ACS Sustainable Chemistry \& Engineering, 2018, 6 (9), 11353-11359.

11. J. Brem, L.C. Bencze, A. Liljeblad, M.C. Turcu, C. Paizs, F.D. Irimie, L.T. Kanerva, Eur. J. Org. Chem., 2012, 17, 3288-3294. 
12. E. Farkas, M. Oláh, A. Földi, J. Kóti, J. Éles, J. Nagy, C.A. Gal, C. Paizs, G. Hornyánszky, L. Poppe, Org. Lett., 2018, 20 (24), 8052-8056.

13. D. Leonte, L. Bencze, C. Paizs, M. Toşa, V. Zaharia, F. Irimie, Molecules, 2016, 21 (1), 25.

14. M.A. Naghi, L.C. Bencze, J. Brem, C. Paizs, F.D. Irimie, M.I. Toşa, Tetrahedron: Asymmetry, 2012, 23 (2), 181-187.

15. K. Li, T. He, C. Li, X. W. Feng, N. Wang, X. Q. Yu, Green Chemistry, 2009, 11, 777-779.

16. T. He, K. Li, M. Y. Wu, X. W. Feng, N. Wang, H. Y. Wang, C. Li, X. Q. Yu, J. Mol. Catal. Enzym., 2010, 67, 189-194.

17. D. Leonte, L.C. Bencze, C. Paizs, F.D. Irimie, V. Zaharia, Molecules, 2015, 20(7), 12300-12313.

18. I. Simiti, M. Farkas, S. Silberg, Chem. Ber., 1962, 95, 2672-2679. 